\title{
Identification of Proteomic Components Associated with Resistance to Fusarium Head Blight in Rye
}

\author{
Dawid Perlikowski ${ }^{1}$, Halina Wiśniewska ${ }^{1}$, Tomasz Góral ${ }^{2}$, Piotr Ochodzki ${ }^{2}$, Maciej Majka ${ }^{1}$, \\ Izabela Pawłowicz ${ }^{1}$, Jolanta Belter ${ }^{1}$, and Arkadiusz Kosmala (1) ${ }^{1 *}$ \\ ${ }^{1}$ Institute of Plant Genetics, Polish Academy of Sciences, 60-479 Poznan, Poland \\ ${ }^{2}$ Plant Breeding and Acclimatization Institute - National Research Institute, 05-870 Blonie, Poland
}

(Received on November 29, 2018; Revised on April 1, 2019; Accepted on April 9, 2019)

Rye was used here to dissect molecular mechanisms of resistance to Fusarium head blight (FHB) and to go deeper with our understanding of that process in cereals. F. culmorum-damaged kernels of two lines different in their potential of resistance to FHB were analyzed using two-dimensional gel electrophoresis and mass spectrometry to identify resistance markers. The proteome profiling was accompanied by measurements of $\alpha$ - and $\beta$-amylase activities and mycotoxin content. The proteomic studies indicated a total of 18 spots with clear differences in protein abundance between the more resistant and more susceptible rye lines after infection. Eight proteins were involved in carbohydrate metabolism of which six proteins showed a significantly higher abundance in the resistant line. The other proteins recognized here were involved in stress response and redox homeostasis. Three remaining proteins were associated with protease inhibition/resistance and lignin biosynthesis, revealing higher accumulation levels in the susceptible rye line. After inoculation, the activities of $\alpha$ - and $\beta$-amylases, higher in the susceptible line, were probably responsible for a higher level of starch decomposition after infection and a higher susceptibility to FHB. The presented results could be a good refer-

\footnotetext{
*Corresponding author.

Phone) +48 (61) 6550 285, FAX) +48 (61) 6550301

E-mail) akos@igr.poznan.pl

ORCID

Arkadiusz Kosmala

https://orcid.org/0000-0002-1760-1334

(c) This is an Open Access article distributed under the terms of the Creative Commons Attribution Non-Commercial License (http:// creativecommons.org/licenses/by-nc/4.0) which permits unrestricted noncommercial use, distribution, and reproduction in any medium, provided the original work is properly cited.
}

Articles can be freely viewed online at www.ppjonline.org. ence for further research to improve crop resistance to FHB.

Keywords : FHB, Fusarium, proteome, resistance, rye

Handling Editor : Kim, Ki Woo

The important cereals, including wheat (Triticum aestivum L.), barley (Hordeum vulgare L.), oat (Avena sativa L.), triticale (xTriticosecale Wittm.) and rye (Secale cereale L.), cultivated in different climatic zones, can suffer from Fusarium head blight (FHB). The disease is caused by numerous fungal pathogens that belong to the Fusarium genus (Bottalico, 1998; Bottalico and Perrone, 2002; Kiecana and Mielniczuk, 2010; Muthomi et al., 2008; Šrobárová et al., 2008). In small-grain cereals, ca. 20 different Fusarium species are thought to be associated with FHB symptoms (Gerlach and Nirenberg, 1982). These fungal species attack cereals in a wide range of environmental conditions. Warmer areas are dominated by $F$. graminearum and cold areas by $F$. avenaceum while $F$. culmorum occupies the intermediate temperature range (Bottalico and Perrone, 2002; Parry et al., 1995; Xu et al., 2005). In Poland and Germany, FHB in rye is caused primarily by $F$. culmorum, $F$. graminearum and Microdochium nivale differentiated from $\mathrm{Fu}$ sarium genus (Kiecana and Mielniczuk, 2010; Lees et al., 1995; Miedaner et al. 2001, 2003).

The fungal infection of plant heads and kernels results both in significant reductions of a grain yield and the contamination with Fusarium toxic metabolites which influence human and livestock health (Desjardins, 2006; Pirgozliev et al., 2003). The disease symptoms are mainly the result of contamination of Fusarium-damaged kernels (FDK) with such compounds as zearalenone (ZEN) and trichothecene B toxins, namely nivalenol (NIV) and 
deoxynivalenol (DON) (Bottalico and Perrone, 2002; Buerstmayr et al., 2009; Chakraborty et al., 2006; Marin et al., 2013).

The selection of plants with high resistance to FHB is difficult since this is regulated both by the genes of host plant and pathogen, and also by external, environmental conditions (Chełkowski et al., 2000; Cowger et al., 2009; Mesterházy, 1995; Miedaner, 1997; Snijders, 2004). In our previous work, we found that some important cellular components of wheat (Perlikowski et al., 2014) and triticale (Perlikowski et al., 2016) are associated with resistance to FHB. Although Langevin et al. (2004) demonstrated that rye is less susceptible to infections of Fusarium species compared to wheat and triticale, rye can also suffer significantly from FHB. Thus, the work performed here is required to complete the comprehensive research and to draw a more comprehensive model of resistance mechanisms in cereals.

The application of proteomic tools has proved to be a valuable strategy to recognize numerous cellular mechanisms involved in the resistance to a broad range of environmental stresses, abiotic and biotic, in different plant species (e.g. Kosmala et al., 2009, 2012; Perlikowski et al., 2014, 2016). In this paper for the first time, we reported the research on rye, involving the analysis of protein accumulation profiles in the FDK of two plant groups, more resistant and more susceptible lines to FHB. The proteome profiling in the analyzed kernels, was complemented by $\alpha$ and $\beta$-amylase activity assays, the evaluation of pathogen content and the accumulation level of DON.

\section{Material and Methods}

Plant material and field experiments. The details associated with field experiments, including fungal material and analysis of plant resistance components were similar to those described previously for wheat (Perlikowski et al., 2014) and triticale (Perlikowski et al., 2016).

Two Polish cultivars of rye, Tur and Horyzo, were used in this research. Their levels of resistance were evaluated under the field conditions in 2016, in two locations: Radzików (central Poland; GPS coordinates: N 52.211754, E 20.631954) with rich, sandy-clay soil and Cerekwica (western Poland; GPS coordinates: N 52.521012, E 16.692005 ) with poor, sandy-clay soil. The pathogen material was a mixture of three isolates of $F$. culmorum (W.G. Sacc.): KF 846 (DON chemotype), KF 350 (NIV chemotype) and ZFR 112 (ZEN type) (Góral et al., 2019). Equal volumes of conidial suspensions of these three isolates were mixed (Góral et al., 2016). The flowering rye heads (65 ZGS) were inoculated by spraying with the spore suspension at a rate of approximately $100 \mathrm{ml} / \mathrm{m}^{2}$. Conidia concentration was adjusted to $5 \times 10^{4} \mathrm{conidia} / \mathrm{ml}$. The experiments in both locations were performed using the same design and all the details were described precisely in our earlier studies on wheat (Perlikowski at al., 2014) and triticale (Perlikowski et al., 2016). The FHB index (FHBi) was calculated according to the formula: FHBi $(\%)=(\%$ of head infection $\times \%$ of heads infected per plot) $/ 100$, as described precisely earlier (Perlikowski at al., 2014).

Pathogen biomass and mycotoxin content. The pathogen biomass and the level of deoxynivalenol accumulation in the kernels of the $\mathrm{R}$ (with a higher resistance) and the $\mathrm{S}$ (with a lower resistance) rye lines were evaluated as described in detail by Perlikowski et al. (2016).

Proteome profiling and identification of differentially accumulated proteins. The plants from Cerekwica were applied into the proteomic research using two-dimensional gel electrophoresis (2-DE) and mass spectrometry (MS). The FDK derived from 20 heads were pooled, separately for each inoculated plot, giving three separate pooled samples (bulk flour) for each analyzed line, the $\mathrm{R}$ and the $\mathrm{S}$. The kernels derived from 20 heads of the control plot were also pooled for each analyzed line. The pooled samples (bulk flour) were used for proteomic research - each one in three technical replicates. The proteomic protocol was the same as that described in detail by Perlikowski et al. (2014, 2016). The proteins were resolved in the $\mathrm{pH}$ range $=4-7$ during isoelectrophocusing, followed by SDS-PAGE, coomassie brilliant blue staining and ImageMaster 2-D Platinum 6.0 (GE Healthcare) processing. The presented here raw 2-D images cannot reveal protein abundance for comparisons. To compensate for differences in sample loading, gel staining and destaining, the abundance of each protein spot was normalized as a relative volume $(\% \mathrm{Vol})$. The $\%$ Vol of each spot was automatically calculated by Image Master software as a ratio of the volume of particular detected spot to the total volume of all the spots marked on the gel. This procedure has been applied in our numerous previous experiments focused on the resistance of plants to biotic (e.g. Perlikowski et al., 2014, 2016) and abiotic stresses (e.g. Augustyniak et al., 2018). The protein identification in the selected spots was performed in the Mass Spectrometry Lab, Institute of Biochemistry and Biophysics, Polish Academy of Sciences (Warsaw, Poland). The identified proteins were grouped according to UniProt categories (www.uniprot.org). 
$\alpha$ - and $\beta$-amylase activity assays. $\alpha$-amylase and $\beta$-amylase activities in rye FDKs were tested using the Ceralpha $\alpha$-Amylase Assay Kit and the "Betamyl- $3^{\circledR}$ method" Assay Kit (Megazyme International Ireland Inc., Bray, Ireland), respectively, as described in our earlier work on triticale (Perlikowski et al., 2016).

\section{Results and Discussion}

Field experiments and DON analysis. Herein, the mixture of three Fusarium isolates was used. This mixture was applied in our numerous experiments and it was proved to be efficient also in uncomfortable environmental conditions to develop the symptoms of Fusarium head blight in different cereal species (e.g. Perlikowki et al., 2014, 2016). The presented studies revealed that Fusarium head infection of both analyzed here rye cultivars was relatively low (Table 1). This phenomenon was supported by earlier reports, suggesting that rye is one of the most resistant species among the other cereals (Langevin et al., 2004). Thus rye could be a good source of genes governing resistance to FHB to be transferred to susceptible plants, as we proved for wheattriticale (Perlikowski et al., 2014, 2016) and could also be the strongest model for resistance. However, the selection of rye individuals with distinct levels of resistance is required to dissect the resistance to FHB into its particular components. The difference in FHB index (associated with type I and type II resistance) was not statistically significant, although higher for the $\mathrm{S}$ line compared to the $\mathrm{R}$ line. Furthermore, as we demonstrated in Table 1, FHBi observed for both field locations (Cerekwica and Radzikow) was also different. This phenomenon was probably due to the different levels of rainfall and temperature in both locations (Supplementary Table 1). However, that important aspect was not analyzed here in details and requires further research. The analyzed rye lines were also significantly different with respect to mycotoxin amounts in the kernels in Cerekwica (Table 1), and these relationships were similar to those observed earlier in our research on triticale (Perlikowski et al., 2016). However, as indicated in Table 2, the $\mathrm{R}$ and $\mathrm{S}$ lines did not differ significantly in the pathogen biomass of the analyzed kernels (a slightly lower fungus biomass was revealed after inoculation in the $\mathrm{R}$ line but this evaluation was not statistically significant). We clearly showed that fungal activity was higher in the more susceptible rye genotypes, at least with respect to DON production. And finally, this phenomenon resulted in significant differences in both numbers and weights of Fusarium damaged kernels observed between the analyzed populations.

Table 2. Fusarium culmorum biomass in the kernels of more resistant (R) and more susceptible (S) rye lines [mg/g]

\begin{tabular}{lcc}
\hline Rye lines & $\begin{array}{c}\text { Conditions after } \\
\text { inoculation }\end{array}$ & $\begin{array}{c}\text { Control } \\
\text { conditions }\end{array}$ \\
\hline R (TUR) & $9.59668( \pm 1.12)^{\mathrm{b}}$ & $0.735388^{\mathrm{a}}$ \\
$\mathrm{S}($ HORYZO) & $11.09539( \pm 1.07)^{\mathrm{b}}$ & $0.781604^{\mathrm{a}}$ \\
\hline
\end{tabular}

$\mathrm{R}$ - more resistant line, $\mathrm{S}$ - more susceptible line; mean values and standard errors of each parameter calculated after inoculation (three plots) and data from one plot calculated for the control conditions, are shown. Values marked with the same letter did not differ at a significance level of 0.05 (Fisher's LSD-test).

Table 1. The components of the resistance to Fusarium head blight in the more resistant (R) and more susceptible (S) rye lines and their yields under control conditions

\begin{tabular}{|c|c|c|c|c|c|c|c|c|c|}
\hline \multirow[b]{2}{*}{ Rye lines } & \multirow[b]{2}{*}{ Location } & \multicolumn{6}{|c|}{ Conditions after inoculation } & \multicolumn{2}{|c|}{ Control conditions } \\
\hline & & FHBi & $\begin{array}{c}\% \text { FDK } \\
\text { (weight [g]) }\end{array}$ & $\begin{array}{l}\% \text { FDK } \\
\text { (number) }\end{array}$ & $\begin{array}{c}\text { Total kernel } \\
\text { number/head }\end{array}$ & $\begin{array}{c}\text { Total kernel } \\
\text { weight }[\mathrm{g}] / \\
\text { head }\end{array}$ & $\begin{array}{c}\text { DON } \\
{[\mathrm{mg} / \mathrm{kg}]}\end{array}$ & $\begin{array}{c}\text { Total kernel } \\
\text { number/head }\end{array}$ & $\begin{array}{c}\text { Total kernel } \\
\text { weight }[\mathrm{g}] / \\
\text { head }\end{array}$ \\
\hline R (TUR) & & $\begin{array}{c}8.0 \\
( \pm 1.41)^{\mathrm{a}}\end{array}$ & $\begin{array}{c}10.5 \\
( \pm 0.73)^{b}\end{array}$ & $\begin{array}{c}15.7 \\
( \pm 3.53)^{b}\end{array}$ & $\begin{array}{c}49.1 \\
( \pm 17.91)\end{array}$ & $\begin{array}{c}1.96 \\
( \pm 0.49)\end{array}$ & $\begin{array}{c}4.75 \\
( \pm 0.25)^{b}\end{array}$ & 50.0 & 2.82 \\
\hline S (HORYZO) & e & $\begin{array}{c}9.0 \\
( \pm 1.41)^{\mathrm{a}}\end{array}$ & $\begin{array}{c}20.9 \\
( \pm 3.18)^{\mathrm{a}}\end{array}$ & $\begin{array}{c}28.2 \\
( \pm 5.22)^{\mathrm{a}}\end{array}$ & $\begin{array}{c}49.1 \\
( \pm 13.63)\end{array}$ & $\begin{array}{c}2.17 \\
( \pm 0.40)\end{array}$ & $\begin{array}{c}6.82 \\
( \pm 0.81)^{\mathrm{a}}\end{array}$ & 54.3 & 2.98 \\
\hline R (TUR) & & $\begin{array}{c}11.7 \\
( \pm 5.51)^{\mathrm{a}}\end{array}$ & $\begin{array}{c}8.8 \\
( \pm 7.19)^{b}\end{array}$ & $\begin{array}{c}9.6 \\
( \pm 7.10)^{b}\end{array}$ & $\begin{array}{c}52.8 \\
( \pm 0.58)\end{array}$ & $\begin{array}{c}2.58 \\
( \pm 0.17)\end{array}$ & $\begin{array}{c}3.86 \\
( \pm 0.44)^{b}\end{array}$ & 53.7 & 2.79 \\
\hline S (HORYZO) & Kadzikow & $\begin{array}{c}14.0 \\
( \pm 3.46)^{\mathrm{a}}\end{array}$ & $\begin{array}{c}11.1 \\
( \pm 0.50)^{b}\end{array}$ & $\begin{array}{c}12.4 \\
( \pm 0.70)^{b}\end{array}$ & $\begin{array}{c}48.6 \\
( \pm 1.50)\end{array}$ & $\begin{array}{c}2.56 \\
( \pm 0.11)\end{array}$ & $\begin{array}{c}4.69 \\
( \pm 1.81)^{b}\end{array}$ & 52.6 & 2.81 \\
\hline
\end{tabular}

FHBi - Fusarium head blight index, FDK - Fusarium-damaged kernels, R - more resistant line, S - more susceptible line; mean values and standard deviations of each parameter calculated after inoculation (three plots) and data from one plot calculated for the control conditions, are shown. Values marked with the same letter did not differ at a significance level of 0.05 (Fisher's LSD-test). 
Interestingly, in triticale, these components of resistance were strongly associated with Fusarium biomass content in the analyzed kernels (Perlikowski et al., 2016), stressing the importance of species specific response to environmental stresses. We hypothesize that significant, albeit subtle, differences in the resistance components identified in the two lines analyzed here could follow crucial alterations in rye cellular proteome in the controlled conditions and after inoculation. These traits make the $\mathrm{R}$ and the $\mathrm{S}$ rye lines excellent and unique models to go deeper in our understanding of resistance to FHB in cereals. Furthermore, the field experiments with wheat (in 2013), triticale (in 2014), and with rye (in 2016), were performed exactly in the same locations but in different years. The environmental conditions were monitored, thus enabling the comparisons between the particular years and the analyzed species with respect to alterations in plant metabolism after infections with the same pathogen materials. However, since such a study does not fall into the scope of this paper, we reserve it for later.

Proteome profiling and identification of differentially accumulated proteins. As clear differences with respect to the level of resistance between the analyzed lines were observed in Cerekwica, the plants grown in that location were selected for proteomic work. The accumulation levels of particular proteins could be good indicators of cellular metabolism, even more informative, compared to the corresponding gene activities evaluated at transcript levels.

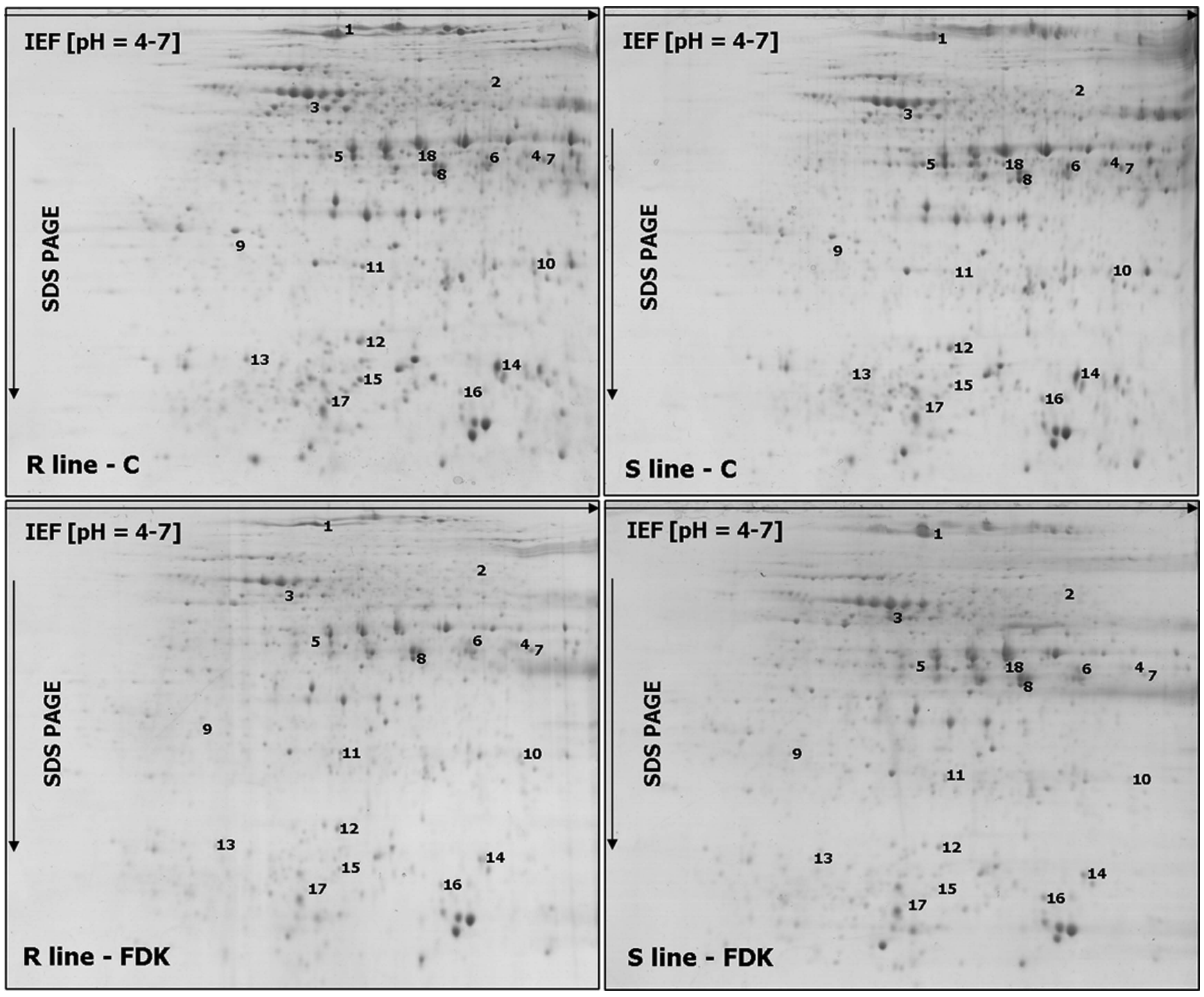

Fig. 1. The single representative 2-DE protein maps of rye kernels in the control conditions (C) and after Fusarium culmorum infection (FDK - Fusarium-damaged kernels) 2-dimensional electrophoresis for the line more resistant (R) and more susceptible (S) to Fusarium head blight. The spots with differentially accumulated $(P \leq 0.05)$ proteins $(1-18)$ between both analyzed lines, are numbered. 
The proteomic experiments demonstrated a total of 18 spots with significant differences in protein accumulation profiles between the analyzed rye lines after infection (Fig.
1 and Supplementary Fig. 1), including 11 spots with significantly higher protein accumulation levels in the $\mathrm{R}$ rye line (spots no. 2, 4, 6-8, and 10-15), and seven spots with

Table 3. The results of MS analysis performed on the spots that showed at least a 2.0 ratio $(P \leq 0.05)$ in protein abundance between the more resistant and more susceptible rye lines

\begin{tabular}{|c|c|c|c|c|c|c|}
\hline $\begin{array}{l}\text { Spot } \\
\text { no. }{ }^{1}\end{array}$ & Accession $^{2}$ & Identified protein ${ }^{3}$ & Score $^{4}$ & $\begin{array}{l}\text { Coverage } \\
(\%)^{5}\end{array}$ & $\begin{array}{l}\text { No. of } \\
\text { peptide } \\
\text { matched }\end{array}$ & Molecular function ${ }^{6}$ \\
\hline 1 & BAK03012 & $\begin{array}{l}\text { predicted protein [Hordeum vulgare subsp. vulgare] } \\
\text { blastp: not identified }\end{array}$ & 338 & 15 & 5 & - \\
\hline 2 & XP_020150703 & $\begin{array}{l}\text { pyrophosphate--fructose 6-phosphate } \\
\text { 1-phosphotransferase, subunit beta-like } \\
\text { [Aegilops tauschii subsp. tauschii] }\end{array}$ & 1117 & 29 & 15 & $\begin{array}{l}\text { carbohydrate } \\
\text { metabolism }\end{array}$ \\
\hline 3 & BAJ85279 & $\begin{array}{l}\text { predicted protein [Hordeum vulgare subsp. vulgare] } \\
\text { blastp: enolase [Aegilops tauschii subsp. tauschii] } \\
\text { XP_020194742 }\end{array}$ & 1493 & 48 & 17 & $\begin{array}{l}\text { carbohydrate } \\
\text { metabolism }\end{array}$ \\
\hline 4 & ANW11921 & $\begin{array}{l}\text { glyceraldehyde-3-phosphate dehydrogenase } \\
\text { [Triticum aestivum] }\end{array}$ & 745 & 34 & 12 & $\begin{array}{l}\text { carbohydrate } \\
\text { metabolism }\end{array}$ \\
\hline 5 & ACN59484 & serpin 2 [Triticum aestivum] & 403 & 13 & 6 & $\begin{array}{l}\text { protease inhibition } \\
\text { (resistance) }\end{array}$ \\
\hline 6 & ACO44683 & fructose-bisphosphate aldolase [Secale cereale] & 900 & 38 & 12 & $\begin{array}{l}\text { carbohydrate } \\
\text { metabolism }\end{array}$ \\
\hline 7 & EMS58841 & fructose-bisphosphate aldolase [Triticum urartu] & 806 & 35 & 10 & $\begin{array}{l}\text { carbohydrate } \\
\text { metabolism }\end{array}$ \\
\hline 8 & ACQ57333 & $\begin{array}{l}\text { cytosolic malate dehydrogenase } \\
\text { [Triticum aestivum] }\end{array}$ & 1528 & 61 & 17 & $\begin{array}{l}\text { carbohydrate } \\
\text { metabolism }\end{array}$ \\
\hline 9 & BAD06321 & $\begin{array}{l}\text { putative caffeoyl CoA O-methyltransferase } \\
\text { [Triticum aestivum }]\end{array}$ & 375 & 22 & 6 & $\begin{array}{l}\text { lignin biosynthesis } \\
\text { (resistance) }\end{array}$ \\
\hline 10 & XP_020172398 & $\begin{array}{l}\text { 1-Cys peroxiredoxin PER1 } \\
\text { [Aegilops tauschii subsp. tauschii] }\end{array}$ & 376 & 22 & 6 & redox homeostasis \\
\hline 11 & P46226 & triosephosphate isomerase [Secale cereale] & 1071 & 52 & 11 & $\begin{array}{l}\text { carbohydrate } \\
\text { metabolism }\end{array}$ \\
\hline 12 & BAK03707 & $\begin{array}{l}\text { predicted protein [Hordeum vulgare subsp. vulgare] } \\
\text { blastp: uncharacterized protein }\end{array}$ & 318 & 42 & 4 & - \\
\hline 13 & - & not identified & - & - & - & - \\
\hline 14 & P12810 & $\begin{array}{l}16.9 \mathrm{kDa} \text { class I heat shock protein } 1 \\
\text { [Triticum aestivum] }\end{array}$ & 821 & 62 & 8 & stress response \\
\hline 15 & Q02400 & $\begin{array}{l}\text { late embryogenesis abundant protein B19.3 } \\
\text { [Hordeum vulgare subsp. vulgare] }\end{array}$ & 234 & 27 & 4 & stress response \\
\hline 16 & AAZ67071 & cereal-type amylase inhibitor [Secale cereale] & 328 & 43 & 4 & $\begin{array}{l}\text { carbohydrate } \\
\text { metabolism }\end{array}$ \\
\hline 17 & - & not identified & - & - & - & - \\
\hline 18 & EMS46390 & serpin-Z2B [Triticum urartu] & 447 & 16 & 7 & $\begin{array}{l}\text { protease inhibition } \\
\text { (resistance) }\end{array}$ \\
\hline
\end{tabular}

${ }^{1}$ Spot numbering was the same as in Fig. 1 and Supplementary Fig. $1 .{ }^{2}$ Database accession (according to NCBInr) of a homologous protein. ${ }^{3}$ Homologous protein and organism from which it originates. ${ }^{4}$ Mascot MudPIT (Multidimensional Protein Identification Technology) score. ${ }^{5}$ Amino acid sequence coverage for the identified proteins; amino acid sequences for the proteins were shown in Supplementary Fig. 2. ${ }^{6}$ Molecular function (www.uniprot.org). 
A

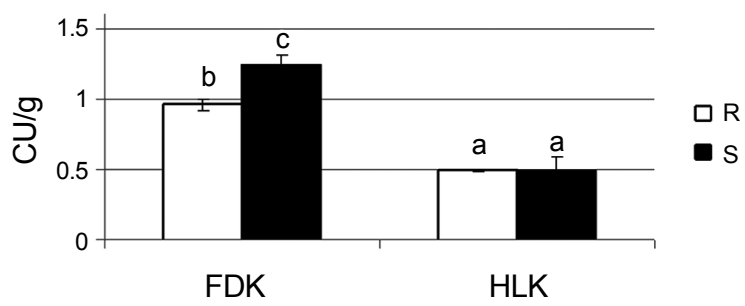

B

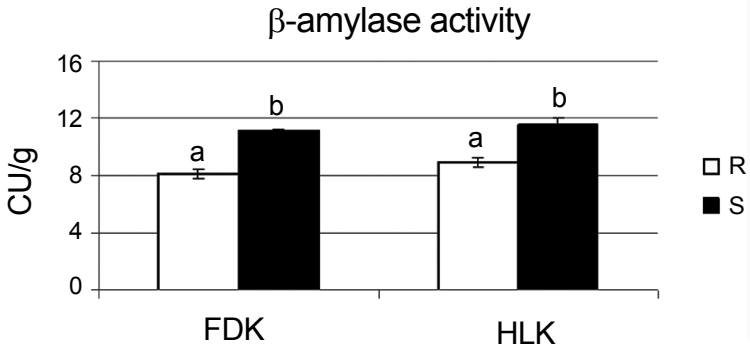

Fig. 2. Comparison of $\alpha$-amylase (A) and $\beta$-amylase (B) activity in the kernels of rye S (line more susceptible to Fusarium head blight) and R (line more resistant to Fusarium head blight) after Fusarium culmorum infection (FDK - Fusarium-damaged kernels) and in control conditions (HLK - healthy looking kernels). The enzyme activity was expressed in Ceralpha Units (CU) per gram of flour. The means of three biological replicates and standard deviation bars are shown. Values marked with the same letter did not differ at a significance level of 0.05 (Fisher's LSD-test).

significantly higher protein accumulation levels in the $\mathrm{S}$ line (spots no. 1, 3, 5, 9, and 16-18). Fourteen proteins were successfully identified using MS approach, whereas four proteins remained unrecognized (spots no. 1, 12-13 and 17). A majority of the identified proteins were shown to be the homologs of proteins from related plant species (Table 3 ). Eight proteins were revealed to be involved in a cellular carbohydrate metabolism (spots no. 2-4, 6-8, 11, and 16) with six proteins showing a significantly higher abundance in the R rye line (Supplementary Fig. 1, Table 3). The importance of carbohydrate metabolism with respect to FHB was revealed also in our earlier work performed on triticale (Perlikowski et al., 2016). The remaining proteins recognized here were demonstrated to be involved in stress response (spots no. 14-15) and redox homeostasis (spot no. 10 ), both types of proteins showing higher abundance after infection in the $\mathrm{R}$ line; three other proteins were confirmed to be associated with protease inhibition/resistance (spots no. 5 and 18) and lignin biosynthesis (spot no. 9), revealing higher accumulation levels in the S line (Supplementary Fig. 1, Table 3).

Previously, we proved the involvements of different types of amylases into the mechanisms of resistance to FHB and the interactions between plants and fungi in wheat and triticale (Perlikowski et al., 2014, 2016). Here, in Fusarium damaged kernels, a significantly higher abundance of cereal-type of amylase inhibitor was revealed for the $\mathrm{S}$ line both at control conditions and after infection (Supplementary Fig. 1). Therefore, a more detailed research on $\alpha-$ and $\beta$-amylase activities were also performed.

$\alpha$ - and $\beta$-amylase activity. Both rye lines did not reveal any significant differences with respect to $\alpha$-amylase activities in the control conditions. On the other hand, after inoculation, the $\alpha$-amylase activities increased significantly in both rye lines, with slightly higher values in the $\mathrm{S}$ line (Fig. 2A). This pattern of $\alpha$-amylase activity shown here for rye was quite similar to those published earlier for wheat (Perlikowski et al., 2014) and triticale (Perlikowski et al., 2016), stressing the importance of this enzyme performance in the mechanism of resistance to FHB in cereals. Interestingly, there was a higher accumulation of cereal-type amylase inhibitor (by combined $2 \mathrm{D}$ and MS analysis) in the $\mathrm{S}$ line. Although amylase activity seems to not correlate with the inhibitor levels, the inhibitor could still be important for pathogensis. The activities of $\beta$-amylase were similar before and after inoculation in each analyzed rye line, however, both in the case of HLK and FDK, these activities were higher in the $\mathrm{S}$ line (Fig. 2B). Thus, FDK of $\mathrm{S}$ rye line showed significantly higher activities of both amylase types, $\alpha$ - and $\beta$-. It has been demonstrated that Fusarium pathogens can use their own hydrolytic enzymes or the enzymes derived from plants to colonize cereal kernels (Wang et al., 2005). This phenomenon was probably responsible, at least partially, for a higher level of starch decomposition after inoculation and higher susceptibility to FHB in the S rye line. On the other hand, a lower level of starch decomposition in the $\mathrm{R}$ rye line did not prevent Fusarium biomass expansion in kernels but reduced significantly its vitality and metabolism. Although, plant and fungal $\alpha$-amylase activities could not be distinguished here, it is highly probable that the amylase activity had its source in both organisms.

\section{Conclusions}

A set of comprehensive experiments which have been performed recently on wheat (Perlikowski et al., 2014), triticale (Perlikowski et al., 2016), and rye (herein) resulted in a model of resistance to FHB in these cereal species in- 
volving crucial components of plant metabolism associated with the stability of kernel storage sugars after Fusarium infection. It has been clearly demonstrated that a higher amylase activity and subsequent starch decomposition were the crucial attributes of higher susceptibility to kernel damage caused by Fusarium in the analyzed cereals. Furthermore, triticale and rye with a lower amylase activities after inoculation were consequently characterized by a lower mycotoxin content in the kernels. However, the correlation between the amylase activities and the susceptibility of rye to Fusarium was not as strong as in the case of wheat and triticale. The presented results could be a good reference for further more applied research to improve crop resistance to FHB.

\section{Acknowledgments}

The study was supported by the Polish Ministry of Agriculture and Rural Development (HORhn - 801 - PB - 9/16 no. 14, 2016). The equipment used for MS was sponsored in part by the Centre for Preclinical Research and Technology (CePT), a project co-sponsored by European Regional Development Fund and Innovative Economy, The National Cohesion Strategy of Poland. Dawid Perlikowski was a scholarshipholder of the Fundation for Polish Science (FNP).

\section{References}

Augustyniak, A., Perlikowski , D., Rapacz, M., Kościelniak, J. and Kosmala, A. 2018. Insight into cellular proteome of $\mathrm{Lo}$ lium multiflorum/Festuca arundinacea introgression forms to decipher crucial mechanisms of cold acclimation in forage grasses. Plant Sci. 272:22-31.

Bottalico, A. 1998. Fusarium diseases of cereals: Species complex and related mycotoxin profiles, in Europe. J. Plant Pathol. 80:85-103.

Bottalico, A. and Perrone, G. 2002. Toxigenic Fusarium species and mycotoxins associated with head blight in small-grain cereals in Europe. Eur. J. Plant Pathol. 108:611-624.

Buerstmayr, H., Ban, T. and Anderson, J. A. 2009. QTL mapping and marker-assisted selection for Fusarium head blight resistance in wheat: A review. Plant Breed. 128:1-26.

Chakraborty, S., Liu, C. J., Mitter, V., Scott, J. B., Akinsanmi, O. A., Ali, S., Dill-Macky, R., Nicol, J., Backhouse, D. and Simpfendorfer, S. 2006. Pathogen population structure and epidemiology are keys to wheat crown rot and Fusarium head blight management. Aust. Plant Pathol. 35:643-655.

Chełkowski, J., Kaptur, P., Tomkowiak, M., Kostecki, M., Goliński, P., Ponitka, A., Ślusarkiewicz-Jarzina, A. and Bocianowski, J. 2000. Moniliformin accumulation in kernels of triticale accessions inoculated with Fusarium avenaceum, in
Poland. J. Phytopathol. 148:433-439.

Cowger, C., Patton-Ozkurt, J., Brown-Guedira, G. and Perugini, L. 2009. Post-anthesis moisture increased Fusarium head blight and deoxynivalenol levels in North Carolina winter wheat. Phytopathology 99:320-327.

Desjardins, A. E. 2006. Fusarium mycotoxins. chemistry, genetics, and biology. APS Press, St. Paul, MN, USA. 260 pp.

Gerlach, W. and Nirenberg, H. 1982. The genus Fusarium - a pictorial atlas. Mitt. Biol. Bundesanst. Land Forstwirtsch. Berl. Dahlem 209:1-406.

Góral, T., Wiśniewska H., Ochodzki, P. and Walentyn-Góral, D. 2016. Higher Fusarium toxin accumulation in grain of winter triticale lines inoculated with Fusarium culmorum as compared with wheat. Toxins 8:301.

Góral, T., Wiśniewska, H., Ochodzki, P., Nielsen, L. K., Walentyn-Góral, D. and Stępień, Ł. 2019. Relationship between Fusarium head blight, kernel damage, concentration of Fusarium biomass, and Fusarium toxins in grain of winter wheat inoculated with Fusarium culmorum. Toxins 11:E2.

Kiecana, I. and Mielniczuk, E. 2010. Fusarium head blight of winter rye (Secale cereale L.) Irena. Acta Agrobot. 63:129135.

Kosmala, A., Bocian, A., Rapacz, M., Jurczyk, B. and Zwierzykowski, Z. 2009. Identification of leaf proteins differentially accumulated during cold acclimation between Festuca pratensis plants with distinct levels of frost tolerance. J. Exp. Bot. 60:3595-3609.

Kosmala, A., Perlikowski, D., Pawłowicz, I. and Rapacz, M. 2012. Changes in the chloroplast proteome following water deficit and subsequent watering in a high and a low drought tolerant genotype of Festuca arundinacea. J. Exp. Bot. 63:6161-6172.

Langevin, F., Eudes, F. and Comeau, A. 2004. Effect of trichothecenes produced by Fusarium graminearum during Fusarium head blight development in six cereal species. Eur. J. Plant Pathol. 110:735-746.

Lees, A. K., Nicholson, P., Rezanoor, H. N. and Parry, D. W. 1995. Analysis of variation within Microdochium nivale from wheat: evidence for a distinct sub-group. Mycol. Res. 99:103109.

Marin, S., Ramos, A. J., Cano-Sancho, G. and Sanchis, V. 2013. Mycotoxins: occurrence, toxicology, and exposure assessment. Food Chem. Toxicol. 60:218-37.

Mesterházy, A. 1995. Types and components of resistance to Fusarium head blight of wheat. Plant Breed. 114:377-386.

Miedaner, T. 1997. Breeding wheat and rye for resistance to Fusarium diseases. Plant Breed. 116:201-220.

Miedaner, T., Reinbrecht, C., Lauber, U., Schollenberger, M. and Geiger, H. H. 2001. Effects of genotype and genotypeenvironment interaction on deoxynivalenol accumulation and resistance to Fusarium head blight in rye, triticale, and wheat. Plant Breed. 120:97-105.

Miedaner, T., Schneider, B. and Geiger, H. H. 2003. Deoxynivalenol (DON) content and fusarium head blight resistance in 
segregating populations of winter rye and winter wheat. Crop Sci. 43:519-526.

Muthomi, J. W., Ndung'u, J. K., Gathumbi, J. K., Mutitu, E. W. and Wagacha, J. M. 2008. The occurrence of Fusarium species and mycotoxins in Kenyan wheat. Crop Prot. 27:12151219.

Parry, D. W., Jenkinson, P. and McLeod, L. 1995. Fusarium ear blight (scab) in small grain cereals-a review. Plant Pathol. 44:207-238.

Perlikowski, D., Wiśniewska, H., Góral, T., Kwiatek, M., Majka, M. and Kosmala, A. 2014. Identification of kernel proteins associated with the resistance to Fusarium head blight in winter wheat (Triticum aestivum L.). PLoS One 9:e110822.

Perlikowski, D., Wiśniewska, H., Kaczmarek, J., Góral, T., Ochodzki, P., Kwiatek, M., Majka, M., Augustyniak, A. and Kosmala, A. 2016. Alterations in kernel proteome after infection with Fusarium culmorum in two triticale cultivars with contrasting resistance to Fusarium head blight. Front. Plant Sci. 7:1217.
Pirgozliev, V. R., Birch, C. L., Rose, S. P., Kettlewell, P. S. and Bedford, M. R. 2003. Chemical composition and the nutritive quality of different wheat cultivars for broiler chickens. $\mathrm{Br}$. Poult. Sci. 44:464-475.

Snijders, C. H. A. 2004. Resistance in wheat to Fusarium infection and trichothecene formation. Toxicol. Lett. 153:37-46.

Šrobárová, A., Šliková, S. and Šudyova, V. 2008. Diversity of the Fusarium species associated with head and seedling blight on wheat in Slovakia. Biologia 63:332-337.

Wang, J., Pawelzik, E., Weinert, J. and Wolf, G. A. 2005. Impact of Fusarium culmorum on the polysaccharides of wheat flour. J. Agric. Food Chem. 53:5818-5823.

Xu, X. M., Parry, D. W., Nicholson, P., Thomsett, M. A., Simpson, D., Edwards, S. G., Cooke, B. M., Doohan, F. M., Brennan, J. M., Moretti, A., Tocco, G., Mule, G., Hornok, L., Giczey, G. and Tatnell, J. 2005. Predominance and association of pathogenic fungi causing Fusarium ear blightin wheat in four European countries. Eur. J. Plant Pathol. 112:143-154. 